УДК 551.89:551.794 (571.642)

\title{
РАННИЙ - СРЕДНИЙ ГОЛОЦЕН СЕВЕРНОГО САХАЛИНА
}

\author{
Микичин Ю. А., Гвоздева И. Г. \\ ФГБУН Дальневосточный геологический институт ДВО РАН, г. Владивосток \\ E-mail: yurimikishin@fegi.ru
}

\begin{abstract}
Новые палинологические и радиоуглеродные данные, полученные по разрезам двух древних торфяников, позволили уточнить ландшафтно-климатические изменения природы первой половины голоцена на южной окраине северного Сахалина. Ранний голоцен отличался в целом более холодными и сухими, по сравнению с современными, климатическими условиями. В растительном покрове преобладали лиственнично-березовые леса с подлеском из кустарниковых берез. В середине бореального периода (9000-8400 л. н. / 10100-9300 к. л. н.) климат стал существенно теплее и немного влажнее, оставаясь по-прежнему суше современного. Широкое распространение получили березовые леса с присутствием широколиственных и темнохвойных пород деревьев. В начальную фазу атлантического периода (вероятно, 7800-7500 л. н. / 8800-8300 к. л. н.), в климатических условиях теплее и значительно влажнее современных, произошла первая экспансия елово-пихтовых лесов. Вторая половина ранней и первая половина средней фазы атлантического периода (7500-6500 л. н. / $8300-7400$ к. л. н.) отличались снижением влажности и дальнейшим потеплением климата, давших преимущество березовым лесам, подчиненную роль елово-пихтовой тайге и большее присутствие широколиственным деревьям. В начале и середине этапа прослеживались два холодных эпизода. Первый из них, около 7300 л. н. / 8100 к. л. н., был сухим и обеспечил возврат березово-лиственничных лесов. Второй, около 7100 л. н. / 7900 к. л. н., имел более влажный климат, вызвавший усиление роли темнохвойной тайги и ослабление - березовых лесов. Во второй половине средней и, возможно, начале поздней фазы периода (вероятно, 6500-5400 л. н. / 7400-6200 к. л. н.) распространились елово-пихтовые леса с участием широколиственных деревьев. Их развитие протекало в обстановке более теплого и влажного климата, аналогичного нынешнему на юге Сахалина, близкого к оптимальным климатическим условиям послеледникового времени. Середина поздней фазы атлантического периода, около 5300 л. н. / 6100 к. л. н., ознаменовалась второй, максимальной экспансией еловопихтовых лесов, из-за наступления прохладного и, возможно, наиболее влажного эпизода в среднем голоцене.
\end{abstract}

Ключевые слова: торфяник, спорово-пыльцевой комплекс, радиоуглеродное датирование, палеоландшафт, палеоклимат, палеопочва.

DOI: 10.34078/1814-0998-2021-1-50-65

\section{ВВЕДЕНИЕ}

Северный Сахалин занимает почти треть острова и отличается от остальной его части развитием обширной равнины (рис. 1). По ее южной окраине, между $51^{\circ} 40^{\prime}$ и $51^{\circ} 20^{\prime}$ с. ш., проходит основная флористическая граница Сахалина, разделяющая лиственничные леса равнинного севера и темнохвойные леса гор остальных частей острова (Толмачев, 1955; Колесников, 1969). Ландшафтно-климатические изменения, происходившие в зоне соприкосновения средне - и южнотаежной растительности, хорошо иллюстрируют эволюцию природы острова в голоцене.

(C) Микишин Ю. А., Гвоздева И. Г., 2021
Первые данные по палеогеографии этой территории в голоцене касались ее западной части (Хотинский, Шулия, 1972; Хотинский, 1977) и были получены при изучении торфяника м. Уанди (рис. 2, разрез № 1). Согласно им, в предбореальном периоде голоцена, 9750-9500 радиоуглеродных лет назад (далее - л. н.) / 11 160-10 900 календарных лет назад (далее - к. л. н.), кустарниковая лесотундра, господствовавшая в позднеледниковье, уступила лидирующее место лесам из березы и ольхи (скорее всего, были развиты лиственнично-березовые леса), но еще сохранила значительное присутствие в растительности. Также появились елово-пихтовые леса с присутствием широколиственных пород. В первую половину бореального периода произошел пер- 
вый послеледниковый расцвет елово-пихтовых лесов, который, вместе с ростом участия широколиственных пород, зафиксировал потепление климата. Последнее усилилось во второй половине бореального периода, около 8400 л. н. / 9300 к. л. н. В эту, самую теплую эпоху голоцена, проявились черты относительной засушливости климата, заметные по сокращению роли темнохвойных лесов. Максимального распространения в голоцене достигли дубово-ильмовые леса (спорово-пыльцевая диаграмма отражает доминирование березовых лесов с примесью широколиственных деревьев). В переходную фазу от бореального к атлантическому периоду, около 7900 л. н. / 8800 к. л. н., в условиях холодного и засушливого климата, участие широколиственных пород в растительности снизилось. Началось распространение зарослей фригидных кустарников и, в меньшей степени, темнохвойной тайги (судя по диаграмме, преобладали лиственнично-березовые леса). В начале атлантического периода широколиственные леса частично восстановились, а роль елово-пихтовой тайги возросла. В более поздние фазы периода, в условиях умеренно теплого и наиболее влажного в голоцене климата, она получила господство в растительности.

Повторное палеоботаническое изучение торфяника м. Уанди было проведено на четырех разрезах (см. рис. 2, № 2-5). Оно касалось, преимущественно, только нижних, придонных горизонтов, и сопровождалось детальным радиоуглеродным датированием (Mikishin et al., 1998). Исследование позволило во многом пересмотреть характер ландшафтно-климатических изменений в начале голоцена и дополнить их для его середины. В начале бореального периода (94009000 л. н. / 10 600-10 100 к. л. н.) было установлено распространение лиственнично-березовых лесов с редким присутствием ели (содержание пыльцы 1-6\%), произраставших в климатических условиях холоднее и суше современных. Следов «первого послеледникового расцвета еловопихтовых лесов», наступившего, по данным Н. А. Хотинского (1977. С. 127), в первую половину бореального периода, не было обнаружено. В то же время подтвердилось существование этапа с более теплым и сухим, относительно современного, климатом («бореальный термический максимум»). Он охва- тил среднюю фазу бореального периода (90008400 л. н. / 10 100-9300 к. л. н.). Сопутствующего этому потеплению «наибольшего за все послеледниковое время распространения широколиственных лесов из дуба и ильмовых» (Хотинский, 1977. С. 127) не было зафиксировано. Максимальное развитие получили березовые леса (48-65\%) с примесью разнообразных широколиственных пород (до $8 \%$ ) с преимуществом ильма. Елово-пихтовые (с преобладанием ели) леса, из-за недостаточной влажности климата, принимали небольшое участие (6-15\%) в растительности, сравнимое с их нынешней ролью на большей части Северо-Сахалинской равнины, занятой лиственничной формацией. Климатический феномен середины бореального периода связывался с отепляющим эффектом Цусимского течения, которое могло проникать в Татарский пролив до северо-западного побережья Сахалина, из-за отсутствия выхода в Охотское море через закрытый тогда пролив Лаперуза. Вторая половина ранней фазы атлантического периода характеризовалась распространением березовых, в меньшей степени елово-пихтовых (15-25\%) лесов с участием широколиственных пород (до $7 \%$ ). Они существовали в условиях, близких по термическому режиму к средней фазе бореального периода, но с большей влажностью, уступавшей, впрочем, современной на северо-западном побережье Сахалина. В позднюю фазу атлантического периода (полученная из интервала 96110 см радиоуглеродная дата около 4500 л. н. / 5200 к. л. н., скорее всего, омоложена, поскольку 


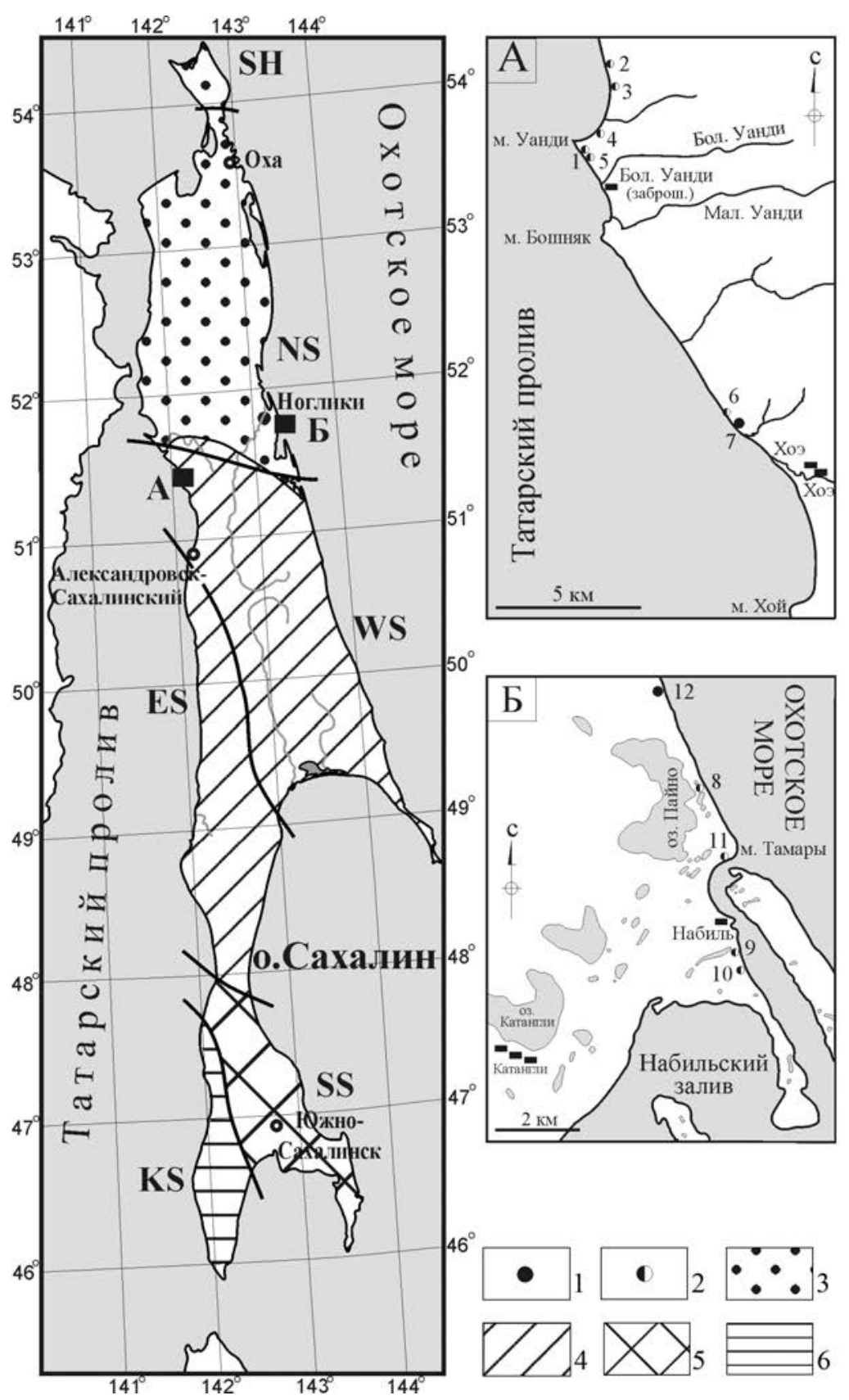

Рис. 2. Расположение разрезов голоценовых отложений на западе (А) и востоке (Б) южной окраины северного Сахалина, использованных при ландшафтноклиматических реконструкциях: 1 разрезы, рассмотренные в данной статье; 2 - разрезы, изученные в прежние годы. 1 - «Уанди» (Хотинский, Шулия, 1972; Хотинский, 1977); 2 - «Уанди-І»; 3 - «Уанди-ІІ»; 4 - «Уанди-ІІІ»; 5 «Уанди-IV» (Mikishin et al., 1998); 6 «Khoe» (Igarashi et al., 2000; Igarashi, Zharov, 2011); 7 - «Хоэ»; 8 - «VI»; 9 «VII» (Александрова, Бровко, 1979); 10 - «Кайган»; 11 - «Набиль» (Микишин, Гвоздева, 2006); 12 - «Пайно». Ботанико-географическое районирование Сахалина (Толмачев, 1955): 3 подзона лиственничных лесов; 4 - подзона зеленомошных темнохвойных лесов с преобладанием ели; 5 - подзона темнохвойных лесов с преобладанием пихты; 6 - подзона темнохвойных лесов с примесью широколиственных пород. Флористические районы Сахалина (Крестов и др., 2004): SH - Шмидтовский, NS - Северо-Сахалинский, WS Западно-Сахалинский, ES - ВосточноСахалинский, SS - Южно-Сахалинский, $\mathrm{KS}$ - Крильонский

Fig. 2. Location of Holocene sections on the southern edge of North Sakhalin in the west (A) and the east (Б); the sections were used in landscape and climate reconstructions. 1 - sections, discussed in this article, 2 - previously studied sections. 1 - Uandi (Khotinsky, Shuliya, 1972; Khotinsky, 1977); 2 - Uandy-I; 3 - Uandy-II; 4 - Uandy-III; 5-Uandy-IV (Mikishin et al., 1998); 6 - Khoe (Igarashi et al., 2000; Igarashi, Zharov, 2011); 7 - Khoe; 8 - VI; 9 - VII (Alexandrova, Brovko, 1979); 10 - Kaigan; 11 - Nabil (Mikishin, Gvozdeva, 2006); 12 - Payno. Botanical-geographical zoning of Sakha-

lin (Tolmachev, 1955): 3 - sub-zone of larch forests; 4 - sub-zone of green-moss dark-needle forests with spruce dominance; 5 - sub-zone of dark-needle forests with fir dominance; 6 - sub-zone of dark-needle forests with broad-leaved tree presence. Floristic districts of Sakhalin (Krestov et al., 2004): SH - Schmidt, NS - North Sakhalin, WS - West Sakhalin, ES - East Sakhalin, SS - South Sakhalin, KS - Crillon

указывает на раннесуббореальное похолодание) развивались елово-пихтовые (25-33\%) и мелколиственные (18-38\%), преимущественно березовые леса. Разнообразные широколиственные породы с преобладанием дуба принимали наибольшее, возможно, за весь голоцен, участие в растительности (до 10\%). Влажность климата, по сравнению с предыдущим событием, увеличилась, а теплообеспеченность превысила уровень «бореального термического максимума». Климатические характеристики, по-видимому, достигали оптимальных значений в голоцене.
Более поздние исследования отложений этого же торфяного массива (Igarashi et al., 2000; Igarashi, Zharov, 2011) были проведены южнее м. Уанди, на разрезе «Кhое», лежащем вблизи пос. Хоэ (см. рис. 2, № 6). Они, на наш взгляд, привели к неоднозначным результатам. Спорово-пыльцевая диаграмма разреза (позднеплейстоценовая история, запечатленная в минеральных отложениях, подстилающих торфяник, здесь не рассматривается) отобразила картину ландшафтно-климатических изменений, ранее установленную для голоцена Саха- 
лина, в том числе и его северо-западного побережья (Хотинский, 1977; Микишин, Гвоздева, 1996; Морские..., 1997; Mikishin et al., 1998; Микишин и др., 2010). Накопление придонных горизонтов торфяника (интервал 340-375 см) отнесено вышеуказанными авторами к позднеледниковью (беллинг / аллеред и молодой дриас), несмотря на то что радиоуглеродные даты около 10000 л. н. / 11500 к. л. н. и 9500 л. н. / 10850 к. л. н. указывают на ранний голоцен. Со временем последнего хорошо увязывается и развитие лиственнично-березовых лесов с зарослями фригидных кустарников и малым участием темнохвойных пород (только ель), отраженное спектрами пыльцевой зоны «5». Вышележащий слой торфяника (глубина 200-340 см, пыльцевая зона «6») отметил экспансию елово-пихтовой тайги с участием широколиственных деревьев, свидетельствующую о наступлении более теплых и влажных климатических условий, характерных для среднего голоцена. В то же время его накопление вышеуказанными авторами связывается с ранним голоценом. При этом образование нижней части этого слоя, в интервале 320-340 см, отнесено к предбореальному периоду, вероятно, на основе положения между горизонтами с абсолютными датами около 9500 л. н. / 10850 к. л. н. и 9400 л. н. / 10650 к. л. н. Последняя из них, с глубины 302 см, по нашему мнению, существенно удревнена, так как резко противоречит характеру палиноспектров с нижним максимумом пыльцы ели (до 60\%). Он однозначно указывает на высокое увлажнение климата, не свойственное раннему голоцену. Накопление нижней части торфяника разреза «К Кое», следовательно, происходило в начале атлантического периода голоцена, а действительный возраст выявленного события, скорее всего, не превышает 8000 л. н. / 8800 к. л. н. Большая часть верхней половины торфяника (глубина 0-200 см, пыльцевая зона «7») формировалась в оптимальных условиях конца средней (датировка около 6300 л. н. / 7300 к. л. н. из низов слоя) и, вероятно, поздней фаз атлантического периода. Они привели к усилению позиций елово-пихтовой тайги (верхний максимум пыльцы ели, до 70\%), ослаблению роли березовых лесов и большему участию широколиственных пород с преобладанием дуба.

На востоке южной окраины северного Сахалина А. Н. Александровой и П. Ф. Бровко (1979) исследовались отложения низкой аккумулятивной террасы побережья Охотского моря (см. рис. 2, № 8, 9). Согласно им, в раннюю фазу суббореального периода голоцена развивалось значительное похолодание климата, которое привело к деградации темнохвойных лесов и распространению кустарниковых зарослей из ольховника, берез и кедрового стланика. В среднюю фазу суббореала
(4300-3400 л. н. / 4900-3650 к. л. н.), в условиях потепления, на прибрежной территории Охотского моря распространялись березово-ольховые леса с примесью дуба и ильма, а темнохвойная тайга не возобновлялась. Заключительные моменты поздней фазы суббореального периода (около 2500 л. н. / 2600 к. л. н.) отметились очередным похолоданием, вызвавшим смену древовидных берез кустарниковыми формами и выпадением из растительного покрова широколиственных пород.

Повторное изучение отложений той же террасы в разрезах «Кайган» и «Набиль» (см. рис. 2, № 10, 11), позволило пересмотреть характер ландшафтно-климатических изменений в суббореальном периоде и дополнить их историю в позднем голоцене (Микишин, Гвоздева, 2006). Вторая половина позднего атлантика (52004700 л. н. / 6000-5450 к. л. н.) обладала наиболее благоприятным климатом, похожим на современные условия южной части Сахалина. Развивались елово-пихтовые (24-49\%) и березовые леса с участием разнообразных широколиственных деревьев (до 10\%). В начале потепления средней фазы суббореального периода, около 4100 л. н. / 4600 к. л. Н., распространялись березово-лиственничные леса с участием темнохвойных и широколиственных пород. Большая часть среднего суббореала (4100-3500 л.н. / 4600-3800 к. л. н. ) была прохладнее и влажнее позднего атлантика, что видно по усилению позиций темнохвойной тайги (34-67\%) и ослаблению широколиственных пород (2-5\%). На заключительной стадии среднего суббореала (3500-3200 л. н. / 3800-3500 к. л. н.) уменьшение влажности климата привело к снижению в растительности роли темнохвойной тайги (33-38\%) и повышению березовых лесов. Около 2500 л. н. / 2600 к. л. н., в климатических условиях, близких к нынешним на северо-востоке Сахалина, в растительности происходило дальнейшее ослабление значения темнохвойных лесов (14$28 \%$ ), распространение лиственничников и зарослей фригидных кустарников. Раннесубатлантическое потепление и увеличение влажности климата вызвало восстановление ведущей роли пихтово-еловых (с преобладанием пихты) лесов с примесью широколиственных деревьев. В середине субатлантического периода, около 1400 л. н. / 1300 к. л. н., они получили максимальное развитие (до 90\%), зафиксировав, видимо, один из наиболее влажных эпизодов в голоценовой истории климата северной части острова.

Как видно по проведенному обзору, наименее освещенными на южной окраине северного Сахалина оставались ландшафтноклиматические изменения первой половины 
среднего, и на ее востоке, в том числе и раннего голоцена. Рассмотреть их позволило изучение двух разрезов древних торфяников, один из которых - «Хоэ», лежит на западном, япономорском побережье острова, другой - «Пайно» - на восточном, охотоморском побережье (см. рис. 2). Оба торфяника занимают сходную геоморфологическую позицию на поверхностях высоких (10-20 м) плейстоценовых терpac, во многом предопределившую накопление в них отложений первой половины голоцена, в основном относящихся к атлантическому периоду. Несмотря на близкое широтное положение, разрезы находятся в разных физикогеографических условиях. Вследствие «климатической асимметрии» о. Сахалин, вызванной охлаждающим воздействием Охотского моря, его западное побережье теплее восточного. Среднегодовые температуры на западе изучаемой территории приближаются к $0^{\circ} \mathrm{C}$, на востоке снижаются почти до $-2^{\circ}$. Среднемесячные температуры наиболее теплого месяца (августа) составляют, соответственно, около 16 и $14^{\circ} \mathrm{C}$, самого холодного - января - около -18 и $-20^{\circ} \mathrm{C}$. Годовая сумма осадков, с максимумом в теплый период (апрель - октябрь) года, близка к 630 мм на обоих побережьях (Справочник..., 1968, 1970; Научно-прикладной..., 1990). Западный разрез - «Хоэ», лежит в подзоне зеленомошных темнохвойных лесов с преобладанием ели, в пределах Западно-Сахалинского флористического района, восточный - «Пайно» - на юго-востоке подзоны лиственничных лесов, в Северо-Сахалинском флористическом районе (Толмачев, 1955; Крестов и др., 2004).

\section{МАТЕРИАЛ И МЕТОДИКА}

Разрезы изучены спорово-пыльцевым и радиоуглеродным анализами. Спорово-пыльцевым анализом исследованы 62 образца отложений, из них 32 - из разреза «Хоэ» и 30 - из «Пайно. Большая их часть отобрана из торфяников с шагом 5 см. Подготовку проб для последующего микроскопирования выполняли по стандартным щелочной и сепарационной методикам, с двукратным обогащением в тяжелой калиево-кадмиевой жидкости (Палеопалинология, 1966). В препаратах насчитывалось 300-500 зерен пыльцы и спор, причем не менее 250 - относящихся к древесным породам. В общем составе спорово-пыльцевых спектров роль пыльцы деревьев и кустарников, фригидных кустарников (кедровый стланик, ольховник и кустарниковые березы), трав и кустарничков, а также спор определяли от всего количества обнаруженных микрофоссилий. Процентное участие компонентов учитывали отдельно в группах пыльцы древесных пород, травянистых растений (включая кустарнички) и среди спор. Содержание таксонов в группе пыльцы древесных пород оценивали без пыльцы низкорослого кустарника восковника (Myrica tomentosa (DC.) Aschers. et Graebn.), имеющей исключительно локальное значение. Реконструкцию палеорастительности выполняли на основе соответствия состава субфоссильных спорово-пыльцевых комплексов современному растительному покрову Сахалина (Микишин, Гвоздева, 2009). Ботанический состав торфа изучен О. Л. Лисс (МГУ). Абсолютный возраст отложений определен М. М. Певзнер в лаборатории геохимии изотопов и геохронологии ГИН РАН, где было получено 14 радиоуглеродных датировок (табл. 1).

Калибровку дат выполняли в программе CALPAL (Weninger et al., 2007). Стратиграфическое расчленение отложений разрезов проводилось в соответствии со схемой периодизации голоцена Блитта - Сернандера, модифицированной для Северной Евразии (Хотинский, 1987).

Таблииа 1. Радиоуглеродные датировки голоценовых отложений северного Сахалина

Table 1. Radiocarbon dates of Holocene sediments from Northern Sakhalin

\begin{tabular}{|c|c|c|c|c|c|c|}
\hline \multirow[b]{2}{*}{$\begin{array}{l}\text { № } \\
\Pi / \Pi\end{array}$} & \multirow[b]{2}{*}{$\begin{array}{c}\text { Разрез, } \\
\text { координаты }\end{array}$} & \multirow[b]{2}{*}{ Лаб. № } & \multirow{2}{*}{$\begin{array}{c}\text { Глубина } \\
\text { отбора, } \\
\text { см }\end{array}$} & \multirow[b]{2}{*}{ Материал } & \multicolumn{2}{|c|}{ Возраст образца } \\
\hline & & & & & $\begin{array}{c}\text { радиоуглеродный, } \\
\text { л. н. }\end{array}$ & $\begin{array}{c}\text { календарный, } \\
\text { к. л. н. }\end{array}$ \\
\hline 1 & \multirow{6}{*}{$\begin{array}{l}\text { «Хоэ» } \\
51^{\circ} 20^{\prime} 04.2^{\prime \prime} \text { с. ш., } \\
142^{\circ} 08^{\prime} 40.5^{\prime \prime} \text { в. Д. }\end{array}$} & ГИН-8605 & $282-285$ & Палеопочва & $8610 \pm 60$ & $9601 \pm 56$ \\
\hline 2 & & ГИН-8606 & $277-282$ & Палеопочва & $9010 \pm 80$ & $10105 \pm 126$ \\
\hline 3 & & ГИН-8588_Г* & $195-200$ & Торф & $7060 \pm 100$ & $7876 \pm 95$ \\
\hline 4 & & ГИН-8588 & $195-200$ & Topф & $6500 \pm 100$ & $7409 \pm 89$ \\
\hline 5 & & ГИН-8589_Г & $120-125$ & Topф & $3580 \pm 40$ & $3894 \pm 51$ \\
\hline 6 & & ГИН-8590_Г & $65-70$ & Торф & $5340 \pm 120$ & $6122 \pm 129$ \\
\hline 7 & \multirow{8}{*}{$\begin{array}{l}\text { «айно» } \\
\text { 51²46'24.5"с. ш., } \\
143^{\circ} 17^{\prime} 25.6^{\prime \prime} \text { в. д. }\end{array}$} & ГИН-7331_Г & $250-255$ & Торф & $6700 \pm 150$ & $7583 \pm 122$ \\
\hline 8 & & ГИН-7330 & $220-230$ & Древесина & $7510 \pm 50$ & $8310 \pm 67$ \\
\hline 9 & & ГИН-7332 & $170-180$ & Древесина & $7400 \pm 50$ & $8247 \pm 59$ \\
\hline 10 & & ГИН-7333 & $110-120$ & Древесина & $6460 \pm 40$ & $7378 \pm 41$ \\
\hline 11 & & ГИН-7334 & $75-80$ & Торф & $790 \pm 40$ & $718 \pm 26$ \\
\hline 12 & & ГИН-7335 & $70-75$ & Topd & $720 \pm 40$ & $676 \pm 21$ \\
\hline 13 & & ГИН-7335 Г & $70-75$ & Торф & $820 \pm 50$ & $747 \pm 43$ \\
\hline 14 & & ГИН-7336 & $65-70$ & Topф & $830 \pm 40$ & $747 \pm 37$ \\
\hline
\end{tabular}

*Даты с индексом «г» получены по щелочной горячей вытяжке, без индекса - по растительным остаткам образца. 


\section{РЕЗУЛЬТАТЫ И ИХ ОБСУЖДЕНИЕ.}

Разрез «Хоэ» заложен на юге обширного торфяника, тяготеющего к м. Уанди и обнажающегося на протяжении 30 км в береговых обрывах Татарского пролива между поселками Хоэ и Виахту (см. рис. 2, № 7). Торфяник залегает на поверхности цокольной террасы высотой 10-20 м, аккумулятивное звено которой сложено верхнеплейстоценовыми аллювиальными отложениями (Александрова, 1982; Igarashi et al., 2000; Igarashi, Zharov, 2011). В расчистке берегового уступа террасы, в 2.6 км северо-западнее пос. Хоэ (51 20 '04.2" с. ш., $142^{\circ} 08^{\prime} 40.5^{\prime \prime}$ в. д.), сверху вниз вскрываются следующие слои, см:

0-7 - лесная подстилка из хвои лиственницы с мелкозернистым песком светло-серого цвета;

7-12 - супесь торфянистая бурого цвета, с включением корней деревьев;

12-16 - песок мелкозернистый светло-серого цвета;

16-25 - суглинок темно-коричневого цвета, с включением корней деревьев;

25-65 - торф травяно-сфагновый, средне разложившийся, темно-бурого цвета, рыхлый, с включением корней деревьев;

65-112 - торф сфагновый, средне разложившийся, черновато-бурого цвета, уплотненный;

112-125 - торф травяно-сфагновый, средне разложившийся, темно-бурого цвета;

125-195 - торф сильно разложившийся, темно-бурого цвета;

195-225 - торф сфагновый, плохо разложившийся, рыжевато-бурого цвета;

225-275 - торф древесно-сфагновый, средне разложившийся, черновато-бурого цвета, с включением большого количества стеблей кустарничков, тонких веток деревьев и кустарников, чешуек шишек кедрового стланика, в интервале 255265 см - крупных веток и коры белой березы;

275-282 - лесная подстилка погребенной почвы: скопление обломков тонких веток деревьев, кустарников и стеблей кустарничков буроваточерного цвета;

282-285 - гумусовый горизонт погребенной почвы: легкий суглинок от буровато-серого до черного цвета, с включением фрагментов веток кустарников и стеблей мхов;

285-290 - глина тугопластичной консистенции, черновато-серого цвета. Ниже осыпь.

На спорово-пыльцевой диаграмме выделяются следующие спорово-пыльцевые комплексы (СПК) и спектры (СПС) (рис. 3).

1. В глинах, подстилающих торфяник, описан СПС «Но-1», в общем составе которого преобладает пыльца фригидных кустарников, далее следуют споры, пыльца деревьев и травянистые растения. Среди пыльцы древесных пород так- же доминируют фригидные кустарники, с ведущей ролью кедрового стланика (62\%), меньшим участием кустарниковых берез (11\%) и ольховника (7\%). Пыльца деревьев представлена елью $(12 \%)$, березами $(8 \%)$ и ольхой $(<1 \%)$. Пыльца трав и кустарничков образована только верескоцветными. Споры принадлежат сфагновым и зеленым мхам. Спектр имеет характерные черты субфоссильного комплекса приморской лесотундры, развитой ныне на узкой полоске морского побережья северо-восточного Сахалина с наименее благоприятными климатическими условиями на острове (Микишин, Гвоздева, 2009). Растительность имела лесотундровый облик, с преобладанием зарослей кедрового стланика и редким участием лиственницы, существовавших в суровых климатических условиях последнего оледенения, скорее всего, его заключительной фазы - позднеледниковья. На склонах низких отрогов Западно-Сахалинского хребта встречались незначительные по площади фрагменты ельников, сходных, вероятно, с современными в подзоне лиственничной тайги острова (Микишин, Гвоздева, 2009).

2. Придонный горизонт торфяника (интервал 275-285 см) содержит СПК «Но-2», в общем составе которого возрастает роль пыльцы деревьев (32-39\%) и снижается участие фригидных кустарников. Среди пыльцы древесных пород в гумусовом горизонте палеопочвы наблюдается преимущество фригидных кустарников (58\%) над мелколиственными породами (39\%). В перекрывающей его лесной подстилке их значение выравнивается (до 46\%). Фригидные кустарники представлены преобладанием кустарниковых (36-50\%), а мелколиственные породы - древовидных берез (3040\%). Участие пыльцы темно-хвойных пород - ели и, единично, пихты, невелико (6-7\%). Еще меньше присутствие светлохвойных пород (1.5\%), представленных лиственницей и сосной (Pinus sgen. Diploxylon). Очень редка пыльца широколиственных деревьев (0.1\%), образованная только ильмом. В группе пыльцы трав и кустарничков преобладают верескоцветные и полынь. Меньшую роль играют травы семейств осоковых, злаковых и разнотравья. Споры образованы обилием сфагновых мхов, папоротниками Polypodiaceae и плаунами. СПК «Но-2» отвечает распространению лиственничноберезовых лесов с широким развитием подлеска из кустарниковых берез. Темнохвойные породы на склонах низких отрогов Западно-Сахалинских гор встречались крайне редко. Растительность существовала в более холодных и сухих климатических условиях, нежели современные. Из отложений палеопочвы получены две радиоуглеродные даты: около 8600 л. н. / 9600 к. л. н. - из нижнего горизонта и около 9000 л. н. / 10100 к. л. н. - из верхнего (см. табл. 1). 


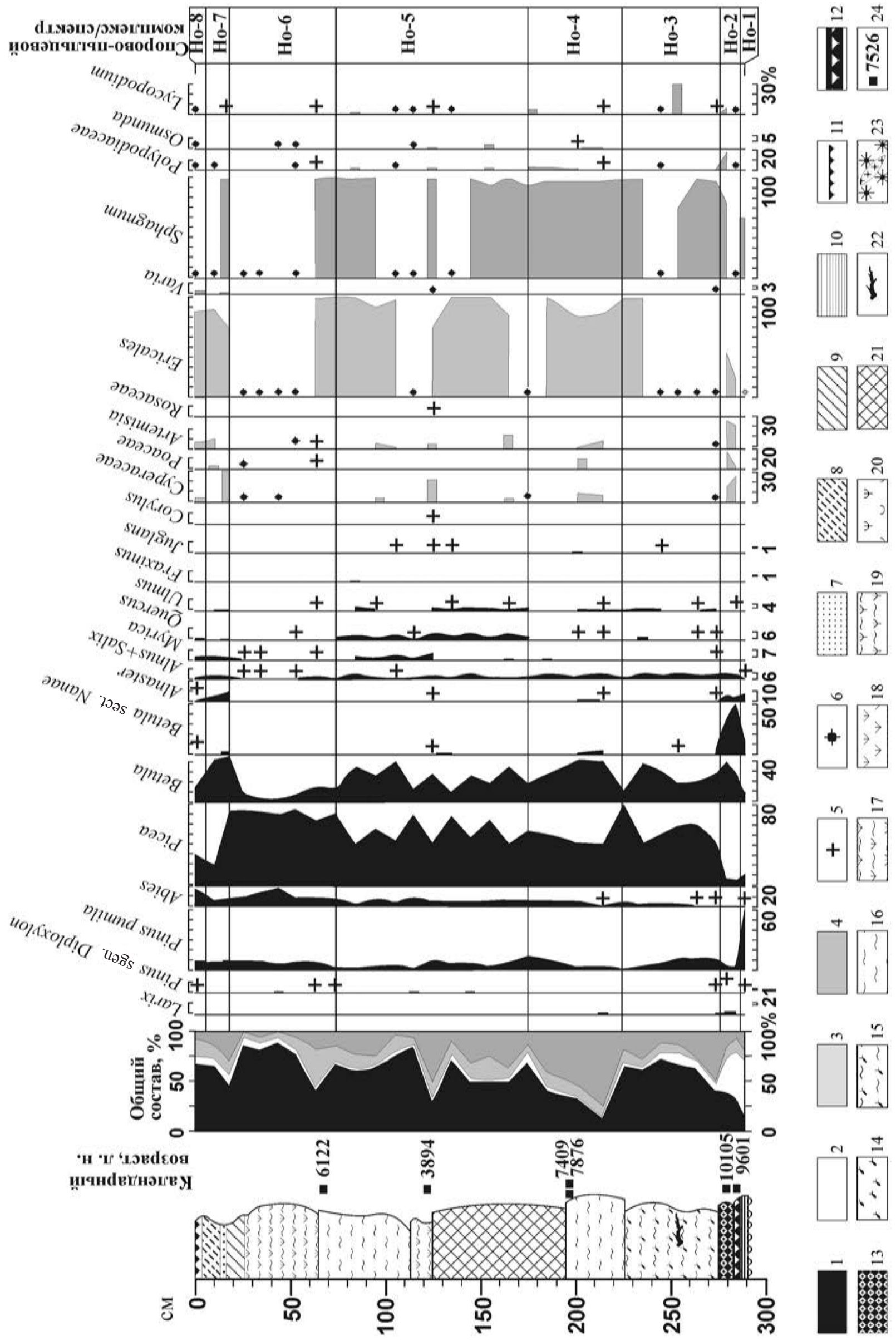


Первая из них явно омоложена. Судя по возрасту аналогичной почвы в этом же торфянике на м. Уанди (Mikishin et al., 1998), омоложение составляет 400-800 лет. Черты комплекса, характерные для отложений раннебореального возраста (Микишин и др., 2010), и результаты радиоуглеродного датирования позволяют отнести обнаруженное палеогеографическое событие к начальной фазе бореального периода голоцена. Возможно, это же похолодание, с абсолютным возрастом около 9000 л. н., ранее было отмечено на юге о. Хоккайдо (Sakaguchi, 1992).

3. Нижний слой торфяника (220-275 см) несет СПК «Но-3». В его общем составе, по сравнению с предыдущим, усиливаются позиции пыльцы деревьев и заметно ослабевают фригидных кустарников. Среди пыльцы деревьев господствуют темнохвойные породы (нижний максимум, до $82 \%$ ) с преобладанием ели и присутствием пихты (до 4\%). Слабее представлена пыльца мелколиственных пород, чаще принадлежащая березам (10-39\%), чем ольхе и ивам (1-6\%). Почти постоянно встречается пыльца широколиственных деревьев (до 6, в среднем 2.2\%), представленная дубом, ильмом и орехом. Пыльцы фригидных кустарников немного, и, почти исключительно, она относится к кедровому стланику (до 13\%). Малочисленная пыльца трав и кустарничков образована верескоцветными. Среди спор доминируют сфагновые мхи, реже отмечаются папоротники Polypodiaceae и плауны. СПК «Но-3» отразил распространение елово-пихтовой тайги, близкой к развитой на среднем Сахалине, но с меньшей ролью пихты и большим присутствием широколиственных деревьев. Климат во время ее произрастания был немного теплее современного и существенно влажнее. Обнаруженное событие происходило в раннюю фазу атлантического периода голоцена, поскольку результаты датирования перекрывающего слоя торфа указывают на первую половину средней фазы периода (около
7100-6500 л. н., см. табл. 1). Скорее всего, оно охватило первую половину фазы, начало которой на Сахалине определено в 7800 л. н. / 8800 к. Л. н. (Микишин и др., 2010).

4. Вышележащий слой (175-220 см) характеризуется СПК «Но-4». В общем составе комплекса, по сравнению с предыдущим, в 2-3 раза снижается роль пыльцы деревьев. Содержание спор, напротив, стремительно возрастает. Среди пыльцы древесных пород по-прежнему лидирует ель, но ее участие снижается до 41-51\%, как и широколиственных деревьев (в среднем менее $1 \%$ ). Роль пыльцы берез, напротив, возрастает до 27-42\%. Среди пыльцы трав и кустарничков преобладают верескоцветные, намного реже осоковые, злаковые и полынь. В группе спор доминируют сфагновые мхи, и, в небольшом количестве, присутствуют папоротники. СПК отразил снижение роли елово-пихтовой тайги и распространение березовых лесов, занимавших в растительности примерно равные позиции. Широколиственные деревья в ней, скорее всего, почти не встречались, в отличие от лесов средней части острова, которым во многом отвечает комплекс. Климатические условия их произрастания были прохладнее и суше нынешних. Обнаруженное событие, возможно, развивалось одновременно с похолоданием «Ключи», зафиксированным на юге острова в начале средней фазы атлантического периода, около 7100-6800 л. н. / 7900-7700 к. л. н. (Микишин, Гвоздева, 2018). Поэтому из двух радиоуглеродных дат - 7100 л. н. / 7900 к. л. н. и 6500 л. н. / 7400 к. л. н., полученных по одному образцу из середины слоя (см. табл. 1), предпочтительнее выглядит более древняя из них.

5. Слой торфа в интервале $75-175$ см имеет СПК «Но-5». В нем восстанавливается ведущая роль пыльцы деревьев и снижается участие спор. Участие пыльцы фригидных кустарников изменяется мало, как и травянистых растений. В группе пыльцы деревьев и кустарников содер-

Рис. 3. Спорово-пыльцевая диаграмма отложений разреза «Хоэ». Пыльца и споры: 1 - пыльца деревьев и кустарников; 2 - пыльца фригидных кустарников; 3 - пыльца трав и кустарничков; 4 - споры; 5 - содержание пыльцы и спор менее 1\%; 6 - процент не подсчитан из-за малого числа обнаруженных зерен пыльцы и спор. Литология: 7 - пески мелкие; 8 - супеси; 9 - суглинки; 10 - глины; 11 - современный дерново-гумусовый горизонт почвы и очес торфяников; 12 - гумусовый горизонт погребенной почвы; 13 - лесная подстилка погребенной почвы; 14 - торф древесный; 15 - торф древесно-сфагновый; 16 - торф сфагновый; 17 - торф осоковосфагновый; 18 - торф осоковый и травяной; 19 - торф пушицево-сфагновый; 20 - торф сосново-пушицевый; 21 - торф сильно разложившийся; 22 - ветки и стволы деревьев; 23 - мерзлота и линзы льда; 24 - радиоуглеродные датировки, к. л. н.

Fig. 3. Spore-pollen diagram of the Khoe section. Pollen and spores: 1 - tree and shrub pollen; 2 - frigid shrub pollen; 3 - herbs and sub-shrubs; 4 - spores; 5 - pollen and spores under $1 \% ; 6$ - percentage not estimated due to small concentrations. Lithology: 7 - fine sands; 8 -silts; 9 - loams; 10 - clays; 11 - modern turfy topsoil horizon and peat bog mats; 12 - humus horizon of buried soil; 13 - forest litter of buried soil; 14 - woody peat; 15 - woody-sphagnous peat; 16 - sphagnous peat; 17 - sedge-sphagnous peat; 18 - sedge and grassy peat; 19 - cotton grass-sphagnous peat; 20 - piny-cotton grass peat; 21 - strongly decomposed peat; 22 - branches and trunks of trees; 23 - frost and ice lenses; 24 - radiocarbon dates, Cal. yrs. BP 
жание пыльцы темнохвойных пород с господством ели увеличивается до уровня отложений ранней фазы атлантического периода (44-78\%). Существенно возрастает роль пыльцы широколиственных пород (в сумме до 9\%). Среди нее чаще отмечается дуб (до 6\%) и ильм (до 4\%), реже opex (Juglans), ясень и лещина (до 1\%). Встречаемость пыльцы мелколиственных пород, в основном берез, как и фригидных кустарников, заметно снижается, соответственно до $12-41$ и 2-14\%. В группе травянистых растений наблюдается прежнее доминирование семейства верескоцветных, среди спор - сфагновых мхов. Состав СПК свидетельствует о распространении елово-пихтовых лесов с участием широколиственных деревьев. Их развитие протекало в условиях, значительно теплее и влажнее современных, аналогичных современному климату на юге острова. Радиоуглеродная датировка около 3600 л. н. / 3900 к. л. н., полученная из середины слоя, сильно омоложена. Действительный возраст обнаруженного события намного больше и, вероятно, отвечает второй половине средней фазы атлантического периода, во время которой климатические условия на юге Сахалина достигали оптимального уровня за весь голоцен (Микишин, Гвоздева, 2017). Результаты датирования ниже- и вышележащих слоев торфяника также свидетельствуют в пользу его развития в средней и, не исключено, в начале поздней фазы атлантического периода. Скорее всего, хронология события определяется рамками 6500-5400 л. н. / 7400-6200 к. л. н.

6. Верхний слой торфяника (16-75 см) заключает СПК «Но-6», с дальнейшим усилением в общем составе роли пыльцы деревьев, при сохранении прежних позиций фригидных кустарников и травянистых растений. Среди пыльцы деревьев и кустарников темнохвойные породы достигают максимального развития (верхний, абсолютный максимум, 72-91\%), причем впервые заметно увеличивается содержание пихты (7-18\%), сравнимое с уровнем субфоссильных спектров средней части Сахалина, занятой елово-пихтовой тайгой. Встречаемость пыльцы мелколиственных пород, преимущественно берез, падает в среднем в 2.5 раза (3-19\%). Реже отмечается и пыльца широколиственных пород (менее $2 \%$ ). Состав СПК свидетельствует о распространении темнохвойных лесов с максимальным развитием ели, существовавших в условиях, близких к современным в районе Хоэ по температурному режиму, но имевших большую влажность. Радиоуглеродная дата около 5300 л. н. / 6100 к. л. н., полученная из нижнего горизонта слоя (см. табл. 1), позволяет отнести событие к середине поздней фазы атлантического периода голоцена.

7. Приповерхностный горизонт торфяника (7-16 см) содержит СПК «Но-7». В его общем составе значение пыльцы деревьев уменьшает- ся, при этом возрастает участие спор и пыльцы фригидных кустарников. Роль пыльцы трав и кустарничков сохраняется на прежнем уровне. Среди пыльцы древесных пород преобладают мелколиственные деревья, в основном березы (43-45\%), а темнохвойные, с преимуществом ели, начинают встречаться реже (2837\%). Участие пыльцы фригидных кустарников возрастает до 11-20\%, в большей степени за счет кедрового стланика и ольховника. Содержание пыльцы широколиственных деревьев (1-2\%) соответствует ее количеству в большинстве субфоссильных проб комплекса елово-пихтовых лесов среднего Сахалина. СПК отразил произрастание лесов, с близким участием темнохвойной и мелколиственной растительности, развивавшихся при температурном режиме, близком к нынешнему климату, но с меньшей влажностью. Событие, скорее всего, происходило в позднюю фазу субатлантического периода голоцена. Косвенно об этом свидетельствует прослой эоловых песков, которые могли поступать в отложения разреза только с морского пляжа, уже находившегося вблизи его современного положения.

8. Лесная подстилка (0-7 см) имеет СПС «Но-8». Он отразил растительность еловопихтовой тайги, сформировавшейся в современных климатических условиях. Среди пыльцы деревьев и кустарников наблюдается преобладание ели $(52 \%)$ и пихты (17\%). Меньшая роль у мелколиственных пород (14\%), почти полностью образованных древовидными березами, и фригидных кустарников (10\%) с преимуществом кедрового стланика. Широколиственные таксоны представлены лишь пыльцой дуба (2\%).

Разрез «Пайно» находится на берегу Охотского моря, вблизи одноименного озеpa $\left(51^{\circ} 46^{\prime} 24.5^{\prime \prime}\right.$ с. ш., $143^{\circ} 17^{\prime} 25.6^{\prime \prime}$ в. д.), в 9 км северо-восточнее пос. Катангли (см. рис. 2, № 12). Представлен торфяником, залегающим на верхнеплейстоценовой аккумулятивной террасе высотой около 20 м. Терраса сложена мерзлыми глинами синевато-черного цвета (из них с глубины 9.8 м по древесине получена радиоуглеродная дата ДВГУ-138 с запредельным - свыше 40 тыс. л. н. - возрастом), перекрытых с поверхности аллювиальными супесями, песками и галечниками. Сверху вниз в расчистке обнажения вскрываются следующие отложения, см:

0-15 - торф пушицево-сфагновый верховой, слабо разложившийся, светло-коричневого цвета, с включением веток кустарников;

15-70 - торф сфагновый верховой, слабо разложившийся, светло-коричневого цвета;

70-100 - торф сосново-пушицевый верховой, средне разложившийся, светло-бурого цвета;

100-150 - торф травяной низинный, средне разложившийся, темно-коричневого цвета; 
150-180 - торф травяно-сфагновый низинный, средне разложившийся, темно-коричневого цвета;

180-235 - торф сфагновый низинный, средне разложившийся, глубже $230 \mathrm{~cm}-$ мерзлый;

235-250 - торф древесно-сфагновый (кора и древесина березы составляет $30 \%$, сфагновый мох $-70 \%)$ низинный, сильно разложившийся, черновато-коричневого цвета, мерзлый;

250-255 - торф древесный (кора и древесина березы составляет $85 \%$, остатки трав и сфагновых мхов - 15\%) низинный, сильно разложившийся, черновато-коричневого цвета, с прослоями супеси светло-желтого цвета толщиной до нескольких миллиметров, не выдержанными по простиранию, мерзлый;

255-262 - гумусовый горизонт погребенной почвы, образованный супесью черного цвета, насыщенной мелкими (1-2, реже 6-12 мм) древесными угольками, мерзлый;

262-295 - супесь желтовато-коричневого цвета с маломощными линзами и прослоями льда, мерзлая.

На спорово-пыльцевой диаграмме разреза выделяются следующие спорово-пыльцевые комплексы и спектры (рис. 4).

1. Поверхностный горизонт (280-293 см) отложений, подстилающих торфяник, содержит СПС «Ра-1». В нем преобладают споры и пыльца фригидных кустарников. Среди пыльцы древесных пород господствуют фригидные кустарники, в основном кустарниковые березы (63\%), реже встречаются ольховник (11\%) и кедровый стланик. Меньшая роль у пыльцы мелколиственных пород, с преимуществом древовидных берез $(16 \%)$ над ольхой и ивами. Пыльца темнохвойных пород присутствует в незначительном количестве (ель до 3\%, пихта - единично), как и широколиственных деревьев (ильм, липа $<1 \%$ ). В группе пыльцы травянистых растений много разнотравья, меньше осоковых и верескоцветных. Споры образованы сфагновыми мхами, папоротниками Polypodiaceae и Osmunda (единично), а также плаунами. СПС «Рa-1» несет характерные черты субфоссильного комплекса приморской лесотундры Сахалина, отражая развитие кустарниковых зарослей с преобладанием ерниковых берез и малым участием лиственницы. Лесотундровая растительность произрастала в холодных климатических условиях последнего оледенения, возможно позднеледниковья.

2. Придонный горизонт торфяника (255262 см) заключает СПК «Ра-2», в общем составе которого на фоне прежнего преобладания спор заметно возрастает роль пыльцы деревьев и снижается присутствие фригидных кустарников. В группе пыльцы деревьев и кустарников первенствуют мелколиственные породы, в основ- ном высокоствольные березы (48-54\%). Второе место у пыльцы фригидных кустарников, с преимуществом ерниковых берез (17-22\%). Пыльцы темнохвойных пород, принадлежащей только ели, немного - 7-14\%. В незначительном количестве $(<1 \%)$ фиксируется и пыльца широколиственных деревьев - дуба и ильма. В группе пыльцы трав и кустарничков много верескоцветных. Реже встречаются полынь, осоковые и розоцветные. Среди спор господствуют сфагновые мхи, присутствуют папоротники Polypodiaceae и плауны. Комплекс «Ра-2» отвечает березоволиственничным лесам с меньшим присутствием ели, чем в нынешней лиственничной тайге на Северо-Сахалинской равнине. Их развитие проходило в условиях, близких к современному климату по термическому режиму, но менее влажных. Об относительной засушливости климата свидетельствует и обилие древесных угольков в палеопочве, свидетелей частых пожаров. Абсолютный возраст обнаруженного события не установлен. Сравнительный анализ составов СПК «Ра-2» и датированных нижнеголоценовых отложений торфяника м. Уанди показывает, что по термофильности оно уступает оптимуму середины бореального периода, но превосходит его раннюю фазу и аллеред (табл. 2). Обнаруженное событие, скорее всего, зафиксировало начальную, теплую фазу предбореального периода.

3. Слой торфяника в интервале $235-255$ см характеризуется СПК «Ра-3», имеющем «среднебореальные» черты, установленные при изучении торфяника м. Уанди. Среди пыльцы древесных пород наблюдается максимум древовидных берез (63-68\%), небольшая примесь ели (7-10\%), фригидных кустарников (8-11\%) и широколиственных пород (до $3 \%$, в среднем $2.5 \%$ ). Количество пыльцы дуба, ильма, ореха сопоставимо с ее средним содержанием в большинстве субфоссильных проб среднего Сахалина и свидетельствует о присутствии этих деревьев, как и ели, в березовых лесах. В напочвенном покрове преобладали верескоцветные кустарнички, реже встречались осоки и полынь. Растительность развивалась в более теплых и сухих, нежели современные, климатических условиях середины бореального периода. В то же время абсолютная дата для этого события, полученная по торфу из нижнего горизонта слоя, указывает на середину атлантического периода - около 6700 л. н. / 7600 к. л. н. (см. табл. 1). Она явно искажена, так как, во-первых, противоречит составу палиноспектров, а во-вторых - моложе вышележащего слоя торфяника. Омоложение возраста составляет не менее 1300 лет и, скорее всего, приближается к 2000 лет, принимая во внимание разброс радиоуглеродных датировок от 9500 до 8000 л. н., полученный для времени послеледникового теп- 


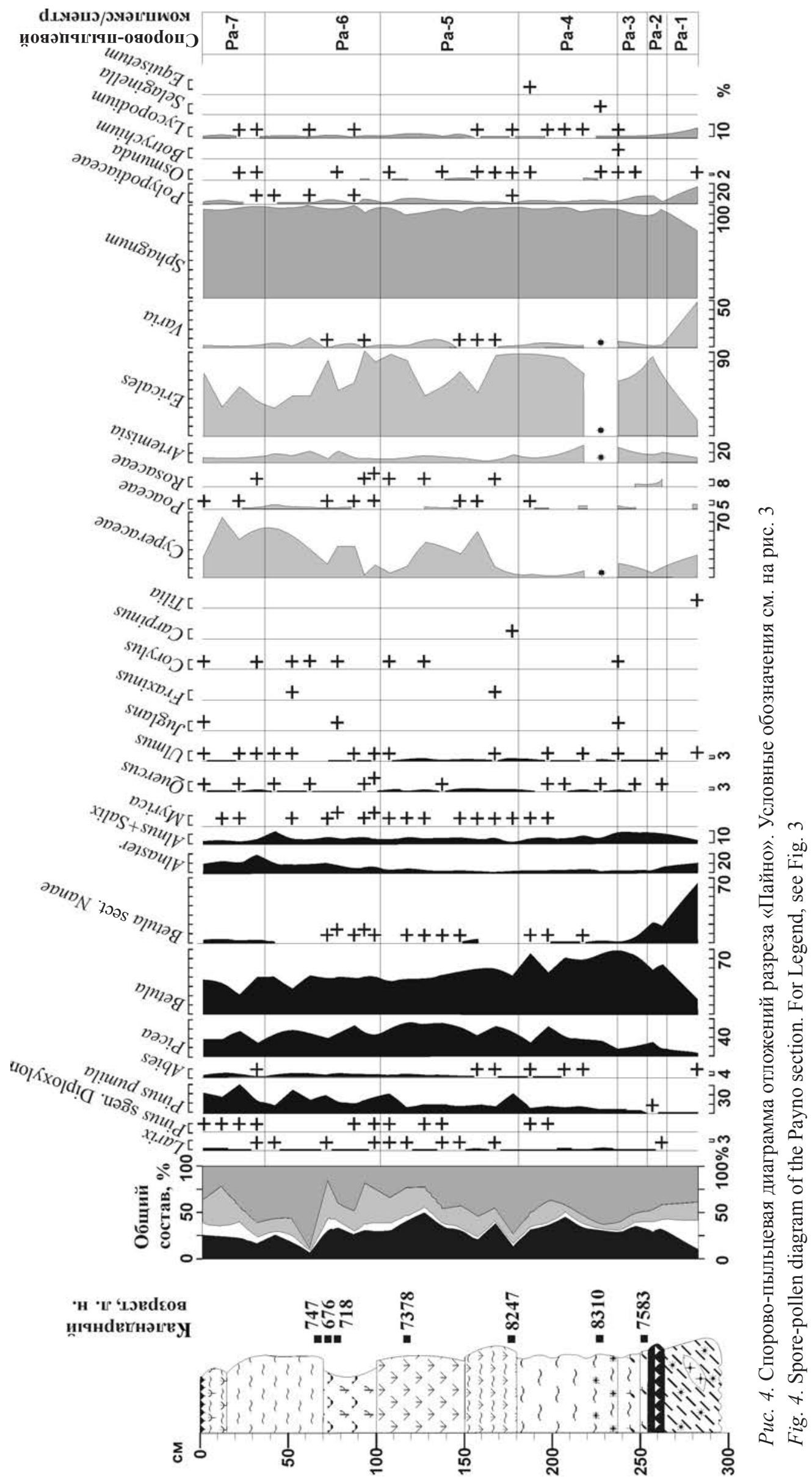


Таблица 2. Состав спорово-пыльцевых комплексов нижнеголоценовых отложений торфяника на м. Уанди (Mikishin et al., 2010) и разреза «Пайно», \% (крайние / средние значения)

Table 2. Composition of the pollen complexes in Lower Holocene sediments at Cape Uandy (Mikishin et al., 2010) and the Payno section, \% (extreme / average values)

\begin{tabular}{|c|c|c|c|c|c|}
\hline \multirow[b]{2}{*}{ Пыльца древесных пород } & \multicolumn{5}{|c|}{ Периоды и фазы голоцена / Спорово-пыльцевые комплексы } \\
\hline & $\begin{array}{c}\text { BO-2 } \\
« \mathrm{U}-\mathrm{II}-2 », \\
\ll \mathrm{U}-\mathrm{III}-3 »\end{array}$ & $\begin{array}{l}\mathrm{BO}-2 \\
« \mathrm{~Pa}-3 »\end{array}$ & $\begin{array}{c}\text { BO-1 } \\
\text { «U-II-3», } \\
\text { «U-III-4», } \\
\text { «U-IV-4» }\end{array}$ & $\begin{array}{c}\text { PB-1 (?) } \\
\text { «Pa-2» }\end{array}$ & $\begin{array}{c}\mathrm{AL} \\
\text { «U-III-2», } \\
\text { «U-IV-2» }\end{array}$ \\
\hline Abies & $0.0-0.8 / 0.2$ & - & - & - & - \\
\hline Picea & $5.0-15.0 / 9.0$ & $7.0-10.0 / 9.0$ & $1.0-6.0 / 3.0$ & $7.0-14.0 / 10.0$ & $0.0-2.0 / 1.0$ \\
\hline Larix & $0.0-1.1 / 0.3$ & $1.0-1.0 / 1.0$ & $1.0-3.0 / 0.1$ & $0.0-0.3 / 0.1$ & $3.0-8.0 / 6.0$ \\
\hline Pinus pumila & $4.0-8.0 / 5.0$ & $3.0-4.0 / 3.0$ & $3.0-16.0 / 10.0$ & $0.7-1.2 / 1.0$ & $17.0-35.0 / 24.0$ \\
\hline Betula sect. Nanae & $3.0-15.0 / 9.0$ & $1.0-5.0 / 3.0$ & $3.0-34.0 / 16.0$ & $17.0-22.0 / 20.0$ & $6.0-17.0 / 11.0$ \\
\hline Alnaster & $0.5-3.0 / 1.5$ & $3.0-3.0 / 3.0$ & $6.0-22.0 / 14.0$ & $3.0-7.0 / 5.0$ & $13.0-28.0 / 21.0$ \\
\hline Myrica & $0.0-0.9 / 0.3$ & - & $0.0-0.3 /<0.1$ & - & - \\
\hline Betula & $49.0-65.0 / 58.0$ & $63.0-68.0 / 66.0$ & $43.0-53.0 / 49.0$ & $48.0-54.0 / 51.0$ & $23.0-36.0 / 30.0$ \\
\hline Alnus + Salix & $5.0-19.0 / 12.0$ & $12.0-13.0 / 12.0$ & $4.0-13.0 / 7.0$ & $11.0-12.0 / 12.0$ & $4.0-8.0 / 6.0$ \\
\hline Quercus & $0.0-1.0 / 0.4$ & $0.6-1.9 / 1.2$ & $0.0-1.0 / 0.2$ & $0.0-0.3 / 0.1$ & $0.0-0.3 /<0.1$ \\
\hline Ulmus & $0.6-7.0 / 4.7$ & $0.6-1.3 / 0.9$ & $0.0-0.6 / 0.3$ & $0.0-0.6 / 0.1$ & $0.0-0.1 /<0.1$ \\
\hline Juglans & $0.0-0.2 /<0.1$ & $0.0-0.3 / 0.1$ & - & - & - \\
\hline Fraxinus & $0.0-0.8 /<0.1$ & - & - & - & - \\
\hline Carpinus & $0.0-0.6 /<0.1$ & - & 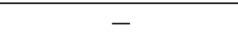 & $\begin{array}{c}- \\
-\end{array}$ & 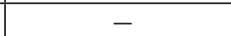 \\
\hline Aralia & $0.0-0.2 /<0.1$ & - & $\begin{array}{l}- \\
\end{array}$ & - & - \\
\hline Vitis & $0-0.2 /<0.1$ & - & - & - & - \\
\hline Corylus & $0-0.3 /<0.1$ & $0.0-0.3 / 0.1$ & - & - & - \\
\hline$\sum$ темнохвойных пород & $5.0-15.0 / 9.0$ & $7.0-10.0 / 9.0$ & $1.0-6.0 / 3.0$ & $7.0-14.0 / 10.0$ & $0.0-2.0 / 1.0$ \\
\hline$\sum$ мелколиственных пород & $68.0-75.0 / 70.0$ & $76.0-81.0 / 78.0$ & $47.0-60.0 / 56.0$ & $60.0-65.0 / 62.0$ & $32.0-41.0 / 34.0$ \\
\hline$\Sigma$ широколиственных пород & $0.6-8.4 / 5.6$ & $1.9-3.1 / 2.5$ & $0.0-1.2 / 0.5$ & $0.0-1 / 0.4$ & $0.0-0.3 /<0.1$ \\
\hline$\Sigma$ фригидных кустарников & $10.0-22.0 / 16.0$ & $8.0-11.0 / 9.0$ & $31.0-50.0 / 40.0$ & $26.0-27.0 / 26.0$ & $47.0-61.0 / 55.0$ \\
\hline
\end{tabular}

лового максимума северо-востока России (Lozhkin, 1993) и во многом отвечающего ему бореального термического максимума Сахалина (Микишин и др., 2010). Эта оценка сопоставима с данными по Камчатке, где давно известное омоложение радиоуглеродных дат (Хотинский, 1977), полученных по торфу из нижних горизонтов торфяников, в отличие от датировок по древесине, может достигать 1-2 тыс. лет (Певзнер, 2015).

4. Торфяник на глубине 180-235 см имеет СПК «Ра-4», с преобладанием в общем составе спор, небольшим присутствием пыльцы древесных пород, травянистых растений и фригидных кустарников. В группе пыльцы деревьев и кустарников, на фоне небольшого ослабления господства мелколиственных деревьев (52-71\%) с ведущей ролью берез происходит значительный, в среднем более чем в 2 раза, рост содержания темнохвойных пород (15-33\%). Доля пыльцы фригидных кустарников незначительна (8-12\%) и ниже, чем в субфоссильных спектрах не только района разреза (в 3 раза), но и юга острова. Количество пыльцы широколиственных деревьев (только дуб и ильм) не превышает 3\%. Пыльца трав и кустарничков почти полностью слагается верескоцветными, полынью и осоковыми. Среди спор господствуют сфагновые мхи и присутствуют папоротники Polypodiaceae. СПК «Рa-4» отразил преобладание березовых лесов и подчиненную роль елово-пихтовой тайги, занимавшей низкие возвышенности на юго-восточной окраине Северо-Сахалинской равнины. Ее развитие происходило в условиях, близких для бореального оптимума, но с большей влажностью климата. Последняя все же не достигала современного уровня, что видно по меньшему участию влаголюбивых темнохвойных лесов. Радиоуглеродная дата около 7500 л. н. / 8300 к. л. н. (см. табл. 1), полученная по древесине из низов слоя, указывает на приуроченность обнаруженного события к середине ранней фазы атлантического периода.

5. Мощный слой торфяника в интервале 100 180 см характеризуется СПК «Ра-5». В его общем составе, по сравнению с предыдущим слоем, падает участие спор и повышается роль травянистых растений. Значение пыльцы деревьев и фригидных кустарников почти не меняется. Состав пыльцы древесно-кустарниковой группы комплекса фиксирует дальнейший рост теплообеспеченности и влажности климата: возрастает участие темнохвойных пород (23-39\%) и разнообразных широколиственных деревьев (до 6, в среднем 4\%). Содержание пыльцы мелколиственных пород, в основном берез, продолжающих лидировать в комплексе, снижается до 40-54\%, что почти в 1.5 раза ниже, чем в предыдущем комплексе. В группе пыльцы трав и кустарничков ослабевает значение преобладающих верескоцветных и усиливается - осоковых, с небольшой примесью полыни и разнотравья. Среди спор господствуют сфагновые мхи. СПК «Ра-5» отража- 
ет ведущие позиции березовых лесов, с возросшей ролью елово-пихтовой тайги, по сравнению с растительностью предыдущей фазы. Примесь широколиственных деревьев возросла, но оставалась ниже, чем в нынешних лесах юга острова. Развитие растительности протекало в более теплых условиях, превышавших современные, но не достигавших уровня термического режима южной части острова. Влажность климата повысилась, но по-прежнему была ниже современной. Судя по радиоуглеродным датам около 7400-6500 л. н. / 8200-7400 к. л. н. (см. табл. 1), событие охватывало вторую половину ранней первую половину средней фазы атлантического периода голоцена.

6. Вышележащий слой торфяника (40-100 см) имеет СПК «Ра-6». В его общем составе, по сравнению с предыдущим комплексом, произошло снижение роли пыльцы деревьев. Небольшой рост наметился среди фригидных кустарников, травянистых растений и спор. В группе пыльцы древесных пород уменьшилось содержание темнохвойных (21-36\%), мелколиственных (31-53\%) и широколиственных деревьев (до 3, в среднем менее $2 \%$ ). Присутствие фригидных кустарников, напротив, возросло до 14-33\%. Среди пыльцы травянистых растений, на фоне падения роли лидирующих верескоцветных, усилилось значение осоковых. В группе спор сохранилось почти полное господство сфагновых мхов. Состав комплекса указывает на преобладание в растительном покрове березово-лиственничных лесов и подчиненную роль елово-пихтовой тайги. Условия произрастания лесов приближались к современным на юго-востоке Северо-Сахалинской равнины по температурному режиму, но уступали им по влажности климата. Серия радиоуглеродных датировок около 800-700 л. н. / 750700 к. л. н. (см. табл. 1) относит событие к началу поздней фазы субатлантического периода голоцена. Климатическая характеристика в большей степени отвечает условиям, сложившимся, вероятно, сразу после потепления VIII-X вв., или «средневекового (малого) оптимума голоцена» (Монин, Шишков, 1979; Микишин, Гвоздева, 1996, 2016; Разжигаева и др., 2014). Поэтому мы связываем его с заключительным моментом средней фазы субатлантического периода, со временем X-XI вв.

7. Верхние горизонты торфяника (0-40 см) заключают СПК «Ра-7», отразивший растительность березово-лиственничных лесов с участием темнохвойных пород. Среди пыльцы деревьев и кустарников происходит резкое, в среднем в 1.5 раза, увеличение доли фригидных кустарников (35-44\%), снижение мелколиственных (23-46\%) и, в меньшей степени, темнохвойных пород (15$29 \%$ ). Состав комплекса отметил похолодание, которое, возможно, соответствует климатическому минимуму XII-XIV вв., зафиксированному как в Европе, так и на Сахалине (Монин, Шишков, 1979; Микишин, Гвоздева, 1996, 2016).

\section{ЗАКЛЮЧЕНИЕ}

Таким образом, новые данные, полученные в результате изучения отложений двух древних торфяников, позволили уточнить эволюцию растительного покрова и оценить масштабы климатических изменений на южной окраине северного Сахалина в первой половине голоцена.

Ранний голоцен характеризовался, в целом, более холодными и сухими, по сравнению с современными, климатическими условиями. Они определяли преобладание в растительности лиственничных лесов, отличавшихся от нынешних на севере острова большим участием древовидных берез. Раннеголоценовые леса подвергались частым пожарам, о чем свидетельствует насыщенность палеопочвенных отложений древесными угольками. Низкая влажность климата не способствовала торфонакоплению, что подтверждается развитием маломощных, часто не более $10 \mathrm{~cm}$, погребенных почв с высокой степенью разложения растительных остатков в гумусовых горизонтах. Реже формировались слои сильно разложившегося торфа небольшой (20-50 см) мощности.

Потепление, происходившее, вероятно, в начале предбореального периода, по термическому режиму приближалось к современному климату, но имело меньшую влажность. В растительности доминировали березово-лиственничные леса с меньшим присутствием ели, чем в нынешней светлохвойной тайге северного Сахалина. Хронология ранней фазы предбореала, согласно данным Н. А. Хотинского (1987), определяется в 10 300-10 000 л. н., которые соответствуют 12 100-11 500 к. л. н.

Ранняя фаза бореального периода отметилась более холодными и сухими по сравнению с современными, климатическими условиями. Происходило распространение лиственнично-березовых лесов с широким развитием подлеска из кустарниковых берез и крайне редкой встречаемостью темнохвойных пород. Согласно прежним исследованиям (Mikishin et al., 1998), событие имело место 9400-9000 л. н., отвечающих 10 600-10 100 к. л. н.

В середине бореального периода, в оптимальную фазу раннего голоцена, произошло существенное потепление, превысившее современный уровень. Климат стал немного влажнее, чем в начале периода, но по-прежнему оставался суше современного. Широкое распространение получили березовые леса с участием разнообразных широколиственных и большим присутствием темнохвойных пород деревьев. Событие укладывается в хронологический интервал 90008400 л. н. (Mikishin et al., 1998), соответствующий $10100-9300$ к. л. н.

Средний голоцен отличался, в целом, более теплыми и влажными климатическими условия- 
ми, параметры которых превышали как раннеголоценовый, так и современный уровень. Их наступление привело к широкому распространению темнохвойной тайги, впервые занявшей ведущие позиции в растительности южной окраины северного Сахалина. Избыточное увлажнение климата положило начало активному торфонакоплению на поверхностях высоких аккумулятивных террас и пологих склонах низких возвышенностей.

В начале ранней фазы атлантического периода, в климатических условиях теплее и влажнее современных, произошла первая в голоцене экспансия елово-пихтовых лесов. От нынешней темнохвойной растительности южной окраины их отличала незначительная роль пихты и большее присутствие широколиственных деревьев. Событие, скорее всего, охватывало возрастной интервал в 7800-7500 л. н. / 8800-8300 к. л. н.

Вторая половина ранней и первая половина средней фазы атлантического периода (75006500 л. н. / 8300-7400 к. л. н.) отличались снижением влажности климата и небольшим потеплением, которые обусловили преобладание в растительности березовых лесов подчиненную роль елово-пихтовой тайги и большее присутствие широколиственных деревьев. В первой половине этапа, около 7300 л. н. / 8100 к. л. н., прослеживался холодный и сухой эпизод, обеспечивший возврат березово-лиственничных лесов, подчиненное участие темнохвойных пород и полное выпадение широколиственных деревьев (Mikishin et al., 1998). Не исключено, что он зафиксировал завершение одного из самых суровых похолоданий голоцена - события «8 тыс. к. л. н.», или «8.2 тыс. к. л. н.» (Alley et al., 1997; Alley, Aguistsdottir, 2005). Второй, холодный и влажный эпизод, вызвавший восстановление темнохвойной тайги и снижение роли березовых лесов, отмечался в середине этапа, около 7100 л. н. / 7900 к. л. н.

Во второй половине средней и, возможно, начале поздней фазы периода (вероятно, 65005400 л. н. / 7400-6200 к. л. н.) распространились елово-пихтовые леса с участием широколиственных деревьев, аналогичные нынешней растительности на юге острова. Их развитие протекало в обстановках, значительно теплее и влажнее современных, приближавшихся к оптимальным в голоцене климатическим условиям, развивавшимся на южной окраине северного Сахалина.

Середина поздней фазы атлантического периода, около 5300 л. н. / 6100 к. л. н., ознаменовалась второй, максимальной экспансией еловопихтовых лесов. Она была вызвана наступлением эпизода, близкого по теплообеспеченности к современной и высокой, возможно, максимальной в среднем голоцене, влажности климата.

Авторы выражают глубокую благодарность М. М. Певзнер (ГИН РАН) за проведение радиоуглеродного датирования торфяников.

\section{ЛИТЕРАТУРА}

Александрова А. Н. Плейстоцен Сахалина. Москва : Наука, 1982. 192 с.

Александрова А. Н., Бровко П.Ф. О суббореальном периоде северного Сахалина // ДАН СССР. 1979. T. 246, № 6. C. 1478-1481.

Колесников Б. П. Растительность // Южная часть Дальнего Востока. Москва : Наука, 1969. С. 206-250.

Крестов П. В., Баркалов В. Ю., Таран А. А. Ботанико-географическое районирование острова Сахалин // Растительный и животный мир острова Сахалин : Материалы международного Сахалинского проекта. Ч. 1. Владивосток : Дальнаука, 2004. С. 67-92.

Микишин Ю. А., Гвоздева И. Г. Эволюция природы юго-восточной части острова Сахалин в голоцене. Владивосток : Изд-во Дальневост. ун-та, 1996. 130 с.

Микишин Ю. А., Гвоздева И. Г. Стратиграфия отложений и палеогеография побережья северо-восточного Сахалина в голоцене // Научное обозрение. 2006. № 3. C. 4-15.

Микишин Ю. А., Гвоздева И. Г. Субфоссильные спорово-пыльцевые комплексы Сахалина и прилегающих территорий. Владивосток : Изд-во Дальневост. ун-та, 2009. 162 с. DOI: 10.17513/np.379.

Микишин Ю. А., Гвоздева И. Г. Поздний субатлантик южного Сахалина // Успехи современного естествознания. 2016. № 9. С. 137-142.

Микишин Ю. А., Гвоздева И. Г. Ландшафтноклиматические изменения на юге Сахалина в среднепозднеатлантическое время голоцена // Успехи современного естествознания. 2017. № 12. С. 207-214. DOI: $10.17513 /$ use.36630.

Микишин Ю. А., Гвоздева И. Г. Следы похолоданий в позднеледниковье и атлантическом периоде голоцена на юге Сахалина // Там же. 2018. № 3. С. 107-116. DOI: $10.17513 /$ use.36711.

Микишин Ю. А., Гвоздева И. Г., Петренко Т. И. Ранний голоцен Сахалина // Актуальные проблемы гуманитарных и естеств. наук. 2010. № 12 (14). C. 432-437.

Монин А. С., Шишков Ю. А. История климата. Ленинград : Гидрометеоиздат, 1979. 407 с.

Морские террасы и четвертичная история шельфа Сахалина / А. М. Короткий, В. С. Пушкарь, Т. А. Гребенникова, Н. Г. Разжигаева, Л. П. Караулова, Л. М. Мохова, Л. А. Ганзей, М. В. Черепанова, В. Б. Базарова, В. Г. Волков, Н. Н. Ковалюх. Владивосток : Дальнаука, 1997. 229 с.

Научно-прикладной справочник по климату СССР. Cер. 3. Многолетние данные. Ч. 1-6. Вып. 34. Сахалинская область. Ленинград : Гидрометеоиздат, 1990. 352 с.

Палеопалинология. Методика палеопалинологических исследований и морфология некоторых ископаемых спор, пыльцы и других растительных микрофоссилий. Ленинград : Недра, 1966. 352 с. (Тр. ВСЕГЕИ; нов. сер.; вып. 141).

Певзнер М. М. Голоценовый вулканизм Срединного хребта Камчатки. Москва : ГЕОС, 2015. 246 с.

Разжигаева Н. Г., Ганзей Л. А., Гребенникова Т. А., Белянина Н. И., Мохова Л. М. Проявления малого оптимума голоцена на юге Дальнего Востока // География и природные ресурсы. 2014. № 2. С. 124-131. 
Справочник по климату СССР. Вып. 34. Сахалинская область.

Ч. 2. Температура воздуха и почвы. Ленинград : Гидрометеоиздат, 1970. 198 с.

Ч. 4. Влажность воздуха, атмосферные осадки, снежный покров. Ленинград : Гидрометеоиздат, 1968. 172 с.

Толмачев A. И. Геоботаническое районирование острова Сахалин. Москва; Ленинград : Изд-во АН CCCP, $1955.78 \mathrm{c}$.

Хотинский Н. А. Голоцен северной Евразии. Москва : Наука, 1977. 200 с.

Хотинский Н. А. Радиоуглеродная хронология и корреляция природных и антропогенных рубежей голоцена // Новые данные по геохронологии четвертичного периода. К XII конгрессу ИНКВА (Канада, 1987 г.). Москва : Наука, 1987. С. 39-45.

Хотинский Н. А., Шулия К. С. Радиоуглеродное датирование и пыльцевая стратиграфия голоценовых отложений Сахалина // Геохимия. 1972. № 11. С. 1412 1415.

Alley R. B., Agustsdottir A. M. The 8K event: Cause and consequences of a major Holocene abrupt climatic change // Quaternary Science Reviews. 2005. Vol. 24. P. 1123-1149.

Alley R. B., Mayewski P. A., Sowers T., Stuiver M., Taylor K. C., Clark P. U. Holocene climatic instability: A prominent, widespread event 8200 yr ago // Geology. 1997. Vol. 25. P. $483-486$.
Igarashi Y., Zharov E. Climate and vegetation change during the Late Pleistocene and Early Holocene in Sakhalin and Hokkaido, Northeast Asia // Quaternary International. 2011. Vol. 237. Iss. 1-2. P. 24-31. DOI 10.1016/j. quaint.2011.01.005.

Igarashi Y., Sagayama T., Higake T., Fukuda M. Late Quaternary environmental change in Central and North Sakhalin, Russia // Journal of Geography. 2000. Vol. 109 (2). P. 165-173.

Lozhkin A. V. Geochronology of Late Quaternary events in northeastern Russia // Radiocarbon. 1993. No. 35. P. 429-433.

Mikishin Yu. A., Gvozdeva I. G., Pevzner M. M. Boreal thermal maximum of Holocene at Sakhalin and the latest data on "Uandy" section / Reports of the 7-th TEACOM Meeting and International Workshop on Global Change Studies in Far East Asia. TEACOM publication No. 4. Vladivostok : Dalnauka, 1998. P. 135-144.

Sakaguchi Y. Cooling of Hokkaido around 9000 BP caused permafrost melt water burst // Bulletin of the Department of Geography University of Tokyo. 1992. No. 24. P. 1-6.

Weninger B., Jöris O., Danzeglocke U. Cologne radiocarbon calibration \& paleoclimate research package. CALPAL_A (Advanced) in the Ghost of Edinburgh Edition. Universität zu Köln, Institut für Ur- und Frühgeschichte, Radiocarbon Laboratory. Weyertal 125, D-50923. - Köln, 2007 [Электрон. peсурс].

Поступила в редакизию 27.08.2020 г.

Поступила после доработки 14.12.2020 2.

\title{
EARLY TO MIDDLE HOLOCENE IN NORTHERN SAKHALIN
}

\author{
Yu. A. Mikishin, I. G. Gvozdeva \\ Far East Geological Institute, FEB RAS, Vladivostok
}

New palynological and radiocarbon data obtained from sections of two ancient peatbogs permitted to specify the landscape and climatic changes in the nature of the first half of the Holocene on the southern outskirts of North Sakhalin. The Early Holocene was generally colder and drier in comparison with modern climatic conditions. The vegetation cover was dominated by larch/birch forests with the shrub birch undergrowth. In the middle of the Boreal Period (9000-8400 yrs. BP / 10, 100-9300 Cal. yrs. BP), the climate became significantly warmer and slightly wetter, yet remaining drier than the modern one. Birch forests with the presence of broad-leaved and dark coniferous tree species were widespread. In the initial phase of the Atlantic Period (probably 7800 7500 yrs. BP / 8800-8300 Cal. yrs. BP), in the climatic conditions warmer and much more humid than modern ones, the first expansion of spruce/fir forests occurred. The second half of the early and first half of the middle phase of the Atlantic Period (7500-6500 yrs. BP / 8300-7400 Cal. yrs. BP) were distinguished by decreased humidity and further warming of the climate, which resulted in dominating birch forests, subordinate spruce/fir taiga, and a lot of deciduous forests. There were two cold episodes at the beginning and in the middle of this stage. The first of them, about $7300 \mathrm{yrs}$. BP / 8100 Cal. yrs. BP, was dry and provided the return of birch/larch forests. The second, about 7100 yrs. BP / 7900 Cal. yrs. BP, had a more humid climate, which caused an increase in the role of dark coniferous taiga and a weakening of birch forests. In the second half of the middle and, possibly, the beginning of the late phase of the period (probably 6500-5400 yrs. BP / 7400-6200 Cal. yrs. BP), spruce/fir forests with participation of broad-leaved tree spread. They developed in a warmer and more humid climate, similar to the current climate in the south of the Sakhalin Island and close to the optimal climatic conditions of the post-glacial time. The middle of the Late Atlantic Period, about 5300 yrs. BP / 6100 Cal. yrs. BP, was marked by the second, maximum expansion of spruce/ fir forests, due to the onset of the cool and, possibly, the wettest episode in the Middle Holocene.

Keywords: peatbog, pollen assemblage, radiocarbon dating, paleolandscape, paleoclimate, buried soil. 


\section{REFERENCES}

Alexandrova, A. N., 1982. Pleistocene in Sakhalin. Moscow, Nauka [In Russian].

Alexandrova, A. N., Brovko, P. F., 1979. On the Subboreal Period in North Sakhalin, Doklady Akademiyi Nauk SSSR. 246 (6), 1478-1481 [In Russian].

Alley R. B., Mayewski, P. A., Sowers, T., Stuiver, M., Taylor, K. C., Clark, P. U., 1997. Holocene Climatic Instability: A Prominent, Widespread Event 8200 yr ago, Geology. 25, 483-486.

Alley, R. B., Agustsdottir, A. M., 2005. The 8K Event: Cause and Consequences of a Major Holocene Abrupt Climatic Change, Quaternary Science Reviews. 24, 1123-1149.

Igarashi, Y., Sagayama, T., Higake, T., Fukuda, M., 2000. Late Quaternary Environmental Change in Central and North Sakhalin, Russia, Journal of Geography. 109 (2), 165-173.

Igarashi, Y., Zharov, E., 2011. Climate and Vegetation Change During the Late Pleistocene and Early Holocene in Sakhalin and Hokkaido, Northeast Asia, // Quaternary International. 237, Iss. 1-2, 24-31. DOI 10.1016/j. quaint.2011.01.005.

Khotinsky, N. A., 1977. Holocene of North Eurasia. Moscow, Nauka [In Russian].

Khotinsky, N. A., 1987. Radiocarbon Chronology and Correlation of Holocene Natural and Anthropogenic Boundaries, New Data on the Geochronology of the Quaternary Period. To the XII Congress INQUA (Canada, 1987). Moscow, Nauka. 39-45 [In Russian].

Khotinsky, N. A., Shuliya, K. S., 1972. Radiocarbon Dating and Pollen Stratigraphy of Holocene Deposits in Sakhalin, Geochemistry International. 11, 1412-1415 [In Russian].

Kolesnikov, B. P., 1969. Vegetation, Southern Part of Russia's Far East. Moscow, Nauka. 206-250 [In Russian].

Krestov, P. V., Barkalov, V. Yu., Taran, A. A., 2004. Phytogeographical Zoning of Sakhalin Island, Flora and Fauna of Sakhalin Island, Materials of International Sakhalin Island Project. Vladivostok, Dalnauka, Part 1. 67-92 [In Russian].

Lozhkin, A. V., 1993. Geochronology of Late Quaternary Events in Northeastern Russia, Radiocarbon. 35, 429-433.

Marine Terraces and the Quaternary History of the Sakhalin Shelf / A. M. Korotky, V. S. Pushkar, T. A. Grebennikova, N. G. Razzhigaeva, L. P. Karaulova, L. M. Mokhova, L. A. Ganzey, M. V. Cherepanova, V. B. Bazarova, V. G. Volkov, N. N. Kovalyukh, 1997. Vladivostok, Dalnauka [In Russian].

Mikishin, Yu. A., Gvozdeva, I. G., 1996. Natural Evolution in the South-Eastern Part of Sakhalin Island in the Holocene. Vladivostok, Far Eastern State [In Russian].

Mikishin, Yu. A., Gvozdeva, I. G., 2006. Stratigraphy of Sediments and Paleogeography of the Coast of NorthEast Sakhalin in the Holocene, Nauchnoe Obozreniye. 3, 4-15 [In Russian].

Mikishin, Yu. A., Gvozdeva, I. G., 2009. Sub-fossil Spore-Pollen Complexes of Sakhalin Island and Adjacent
Areas. Vladivostok, Far Eastern State University. DOI: 10.17513/np.379 [In Russian / In English].

Mikishin, Yu. A., Gvozdeva, I. G., 2016. Late Subatlantic in the South of Sakhalin Island, Advances in Current Natural Sciences. 9, 137-142 [In Russian].

Mikishin, Yu. A., Gvozdeva, I. G., 2017. LandscapeClimatic Changes in the South Sakhalin Island in the Middle-Late Atlantic Time of the Holocene, Ibid. 12, 207-214. DOI: 10.17513/use.36630 [In Russian].

Mikishin, Yu. A., Gvozdeva, I. G., 2018. Traces of Cooling in Southern Sakhalin in the Late Glacial and the Atlantic Period of the Holocene, Ibid. 3, 107-116. DOI: 10.17513/use.36711 [In Russian].

Mikishin, Yu. A., Gvozdeva, I. G., Petrenko, T. I., 2010. Early Holocene in Sakhalin, Actualnyye Problemy Gumanitarnykh i Yestestvennykh Nauk. 12 (14), 432-437.

Mikishin, Yu. A., Gvozdeva, I. G., Pevzner, M. M., 1998. Boreal Thermal Maximum of Holocene at Sakhalin and the Iatest Data on "Uandy" Section, Reports of the 7-th TEACOM Meeting and International Workshop on Global Change Studies in Far East Asia, TEACOM publication, 4. Vladivostok, Dalnauka, 135-144.

Monin, A. S., Shishkov, Yu. A., 1979. History of Climate. Leningrad, Gidrometeoizdat [In Russian].

Paleopalinology. Methodology of Paleopalinological Studies and the Morphology of Some Fossil Spores, Pollen and Other Plant Microfossils. Leningrad, Nedra, 1966. (Tr. VSEGEI, New Ser., Iss. 141) [In Russian].

Pevzner, M. M., 2015. Holocene Volcanism of Sredinny Range in Kamchatka. Moscow, GEOS [In Russian].

Razzhigaeva, N. G., Ganzey, L. A., Grebennikova, T. A., Belyanina, N. I, Mokhova, L. M., 2014. Manifestations of the Holocene Little Climatic Optimum in the South of the Far East, Geography and Natural Resources. 2, 124-131 [In Russian].

Reference Book on the Climate of the USSR. Iss. 34. Sakhalin Oblast.

Part II. Air and Soil Temperature. Leningrad, Gidrometeoizdat, 1970 [In Russian].

Part IV. Humidity, Atmospheric Precipitation, Snow Cover. Leningrad, Gidrometeoizdat, 1968 [In Russian].

Sakaguchi, Y., 1992. Cooling of Hokkaido Around 9000 BP Caused Permafrost Melt Water Burst, Bulletin of the Department of Geography University of Tokyo. 24, 1-6.

Scientific and Applied Handbook on the Climate of the USSR. Leningrad, Gidrometeoizdat, 1990. Iss. 34, Part 1-6, Ser. 3, Long-Term Data [In Russian].

Tolmachev, A. I., 1955. Geobotanical Zoning of Sakhalin Island. Moscow; Leningrad, AN SSSR [In Russian].

Weninger, B., Jöris, O., Danzeglocke, U., 2007. Cologne Radiocarbon Calibration \& Paleoclimate Research Package. CALPAL_A (Advanced) in the Ghost of Edinburgh Edition, Universität zu Köln, Institut für Urund Frühgeschichte, Radiocarbon Laboratory. Weyertal 125, D-50923. Köln [Электрон. peсурс]. 